\title{
PENGARUH SUASANA TOKO DAN LOKASI TERHADAP MINAT \\ BELI KONSUMEN PADA MINI MARKET XMART ULAK KARANG \\ PADANG
}

\author{
MUHAMMAD HUSNI HANDRI, JHON FERNOS \\ Sekolah Tinggi Ilmu Ekonomi KBP \\ Jhonfernos@akbpstie.ac.id
}

\begin{abstract}
This study aims to determine the effect of store atmosphere and location on consumers' buying interest in the XMART mini market of Padang Padang. The sample used is 100 consumers, the sampling technique uses saturated sampling method. Data collection used a questionnaire, while data analysis techniques were performed using multiple linear regression analysis. The results showed that the store atmosphere variable had a positive effect $(4,527>1,6772)$ and significant $(0,000<0,05)$ on consumer buying interest. Location variables have a negative effect $(-0,079)<(1,6772)$ and are not significant $(0,937>0,05)$ to consumer buying interest. From this research, the $R 2$ value is 0,244 , it means that $24,4 \%$ of consumers' buying interest can be explained by the independent variables, namely the store atmosphere and location and the remaining 74,3\% is explained by other variables.
\end{abstract}

Keywords : Store Atmosphere, Location, Consumer Buying Interest

\section{PENDAHULUAN}

Perkembangan ekonomi Indonesia di sektor ritel semakin meningkat. Hal ini terjadi karena pengusaha baik dari dalam maupun luar negeri yang terus menerus melakukan kegiatan dalam mengembangkan usahanya di Indonesia. Fenomena tersebut juga terjadi pada Xmart yang ada di kota Padang. Berdasarkan data yang di peroleh dari Xmart di kota padang dapat di ketahui bahwa sekarang terdapat 3 Xmart yang beroperasi di kota Padang. Xmart berdiri pada tahun 2014 di jalan Diponegoro no.17b, kelurahan belakang tangsi, kecamatan Padang Barat kota Padang. Melihat kondisi persaingan yang semakin ketat, setiap bisnis ritel modern perlu menarik minat beli konsumen untuk melakukan pembelian, dapat dilakukan dengan cara memberikan suasana toko yang menyenangkan bagi konsumen, memberikan diskon ataupun doorprize dan lokasi toko yang mudah diakses.

Menurut (Wibowo, 2015) Suasana toko merupakan salah satu bagian dari bauran eceran yang memiliki arti yang sangat penting dalam menjalankan bisnis ritel. Dengan adanya suasana toko yang baik, maka akan menarik pengunjung dan melakukan pembelian. Dengan adanya suasana toko yang baik maka dalam suatu perusahaan atau organisasi dapat dimungkinkan terjadi peningkatan penjualan, dari suasana toko yang baik karyawan juga dapat modal utama atau mampu menarik pelanggan dengan baik untuk mencapai perusahaan dalam penjualannya.

Selain itu peranan Lokasi juga sangat berpengaruh besar dalam menentukan tingkat penjualan, meningkatkan hasil laba maupun menarik lebih banyak konsumen agar 
mau datang pada perusahaan atau toko. Letak lokasi haruslah nyaman, aman, bersih, ramai dan mudah dijangkau, merupakan kriteria yang diamati oleh banyak konsumen. Dengan demikian, maka ada hubungan antara lokasi yang strategis dengan daya tarik konsumen untuk melakukan pembelian suatu produk.

Tabel 1

Data Perkembangan Penjualan Minimarket Xmart Ulak Karang Bulan Februari 2018 - Juli 2018

\begin{tabular}{ccc}
\hline No & Bulan & $\begin{array}{c}\text { Jumlah Pengunjung } \\
\text { (Konsumen) }\end{array}$ \\
\hline 1 & Februari & 800 \\
\hline 2 & Maret & 1014 \\
\hline 3 & April & 521 \\
\hline 4 & Mei & 603 \\
\hline 5 & Juni & 952 \\
\hline 6 & Juli & 1138 \\
\hline & Jumlah & $\mathbf{5 0 2 8}$
\end{tabular}

Sumber Data Xmart Ulak Karang Padang

Dari data di atas dapat di ketahui bahwa pada bulan Februari 2018 samapai Juli 2018 terjadi fluktuasi jumlah konsumen pada minimarket Xmart Ulak Karang Padang. Berdasarkan latar belakang yang telah diuraikan di atas, peneliti tertarik untuk mengadakan penelitian lebih lanjut mengenai masalah suasana toko dan lokasi yang ada di toko. Untuk itu pada penelitian ini penulis mengambil judul : "Pengaruh Suasana Toko Dan Liokasi Terhadap Minat Beli Konsumen Pada Xmart Di Padang”

\section{Rumusan Masalah}

Berdasarkan uraian dari latar belakang tersebut, maka yang menjadi pokok permasalahan pada penelitian ini adalah:

1. Apakah suasana toko berpengaruh terhadap minat beli konsumen?

2. Apakah lokasitoko berpengaruhterhadap minat beli konsumen?

\section{TINJAUAN PUSTAKA}

\section{Minat Beli}

\section{Pengertian Minat Beli}

Menurut (Adiba, 2016) Minat beli merupakan bagian dari komponen perilaku dalam sikap mengkonsumsi. Minat beli konsumen adalah tahap dimana konsumen membentuk pilihan mereka di antara beberapa produk yang tergabung dalam perangkat pilihan, kemudian pada akhirnya melakukan suatu pembelian pada suatu alternatif yang saling disukainya atau proses yang dilalui konsumen untuk membeli suatu barang atau jasa yang didasari oleh berbagai macam pertimbangan.

\section{Indikator Minat Beli}

Adapun Indikator-indikator minat beli menurut (Wibowo, 2015) sebagai berikut: 
1. Ketertarikan

2. Perhatian

3. Pencarian informasi

\section{Suasana Toko}

\section{Pengertian Suasana Toko}

Menurut (Wibowo, 2015) suasana toko adalah suatu karakteristik fisik yang sangat penting bagi setiap bisnis ritel hal ini berperan sebagai penciptaan suasana yang nyaman sesuai dengan keinginan konsumen dan membuat konsumen ingin berlama-lama berada di dalam toko dan secara tidak langsung merangsang konsumen untuk melakukan pembelian.

\section{Indikator Suasana Toko}

Adapun Indikator-indikato suasana toko menurut (Wibowo, 2015) sebagai berikut:

1. Bagian luar toko

2. Bagian dalam toko

3. Tata letak took

4. Tanda-tanda informasi

\section{Lokasi Toko}

\section{Pengertian Lokasi Toko}

Menurut (Ibrahim, 2017) lokasi adalah tempat di mana perusahaan harus bermarkas melakukan operasi menyatakan bahwa memilih lokasi yangbaik merupakan keputusan yang penting.

\section{Indikator Lokasi Toko}

Menurut (Wibowo, 2015)mengemukakan beberapa komponen yang menjadi pertimbangan pemilihan lokasi, adalah:

1) Penggambaran tempat (ukuran, bentuk)

2) Persyaratan sewa/harga tanah

3) Rasio parkir

4) Arus pejalan kaki

5) Arus lalu lintas (jumlah dan rata-rata kecepatan)

6) Jalan keluar/jalan masuk

7) Akses transportasi umum

8) Visibilitas, penandaan, keadaan sekitar

9) Daya gabung dan afisitas (tetangga)

10) Akses kearah perdagangan

\section{Pengembangan Hipotesis}

\section{Pengaruh Suasana TokoDengan Minat Beli Konsumen}

Menurut (Julianti, Nuridja, \& Meitriana, 2014) Berdasarkan hasil penelitian yang dilakukan mengenai pengaruh suasana toko terhadap minat konsumen berpengaruh segnifikan terhadap minat beli konsumen.

\section{Pengaruh Lokasi Dengan Minat Beli Konsumen}

Menurut (Widiastuti, 2017) Syarat yang harus dipenuhi peritel dalam mendirikan toko atau jenis usaha adalah lokasi atau tempat yang tepat. Maksudnya, konsumen atau pasar sasaran bisa dengan mudah menjangkau lokasi tersebut, baik menggnakan kendaraan sendiri maupun menggunakan kendaraan umum.

\section{Hipotesis Penelitian}

H1: Diduga Suasana Toko berpengaruh positif terhadap minat beli konsumen 
H2: Diduga Lokasi berpengaruh positif terhadap minat beli konsumen

\section{METODE PENELITIAN Jenis Penelitian}

Jenis penelitian ini adalah Penelitian Kuantitatif, penelitian kuantitatif yaitu salah satu metode penelitian dimana data penelitian berupa angka-angka dan analisis menggunakan statistik (Sugiyono, 2015).

\section{Objek atau Lokasi Penelitian}

Objek penelitian merupakan lokasi dimana untuk mendapatkan sejumlah data yang akan dilakukan peneliti pada minimarket X-MART yang berlokasi di Jalan S. Parman No. 137, Ulak Karang Selatan, Padang yang dijadikan sebagai objek dalam penelitian ini.

\section{Populasi}

Populasi yang digunakan dalam penelitian ini adalah semua pelanggan atau orang yang pernah mengunjungi minimarket X-MART yang berlokasi di Jalan S. Parman No. 137, Ulak Karang Selatan, Padang.

\section{Sampel}

Dalam penelitian ini teknik pengambilan sampel yang digunakan adalah sampling jenuh dimana sampling jenuh adalah teknik pengambilan sampel bila semua anggota populasi digunakan sebagai sampel (Sugiyono, 2015). Sampel yang digunakan sebanyak 100 konsumen pada Xmart Ulak Karang

\section{Teknik Pengumpulan Data}

Kuisioner

Kuisioner merupakan teknik pengumpulan data yang dilakukan dengan cara memberi beberapa pertanyaan dan pernyataan tertulis kepada responden untuk dijawabnya (Sugiyono, 2015).

\section{Definisi Operasional Variabel}

Tabel 2

\begin{tabular}{|c|c|c|}
\hline Variabel & Definisi & Indikator \\
\hline $\begin{array}{l}\text { Minat Beli } \\
\text { (Y) }\end{array}$ & $\begin{array}{l}\text { minat beli } \\
\text { adalah } \\
\text { keinginan } \\
\text { untuk memilik } \\
\text { produk, minat } \\
\text { beli akan } \\
\text { timbul apabila } \\
\text { seseorang } \\
\text { konsumen } \\
\text { sudah } \\
\text { terpengaruh } \\
\text { terhadap mutu } \\
\text { dan kualitas } \\
\text { dari suatu } \\
\text { produk, } \\
\text { informasi }\end{array}$ & $\begin{array}{l}\text { a. Ketertarikan, yaitu } \\
\text { ketertarikan konsumen yang } \\
\text { menimbulkan rasa senang puas, } \\
\text { dalam diri seseorang yang dapat } \\
\text { membangkitkan rasa ingin } \\
\text { membeli. } \\
\text { b. } \\
\text { perhatian, yaitu keaktifan } \\
\text { pikiran, akal, ingatan yang dapat } \\
\text { membangkitkan rasa ingin } \\
\text { membeli. } \\
\text { c. } \\
\text { adanya rasa ingin tahu yang } \\
\text { membangkitkan rasa ingin beli }\end{array}$ \\
\hline
\end{tabular}




\begin{tabular}{|c|c|c|}
\hline & $\begin{array}{l}\text { seputar } \\
\text { produk. } \\
\text { Durianto } \\
(2003: 58)\end{array}$ & \\
\hline $\begin{array}{l}\text { Suasana } \\
\text { Toko } \\
\text { (X1) }\end{array}$ & $\begin{array}{l}\text { Suasana Toko } \\
\text { merupakan } \\
\text { kombinasi dari } \\
\text { pesan secara } \\
\text { fisik yang } \\
\text { telah } \\
\text { direncanakan, } \\
\text { atmosphere } \\
\text { toko dapat } \\
\text { digambarkan } \\
\text { sebagai } \\
\text { prubahan } \\
\text { terhadap } \\
\text { perancangan } \\
\text { lingkungan } \\
\text { pembelian } \\
\text { yang } \\
\text { menghasilkan } \\
\text { efek emosional } \\
\text { khusus yang } \\
\text { dapat } \\
\text { menyebabkan } \\
\text { konsumen } \\
\text { melakukan } \\
\text { tindakan } \\
\text { pembelian. } \\
\text { Gilbert (Foster } \\
\text { 2008:61) }\end{array}$ & $\begin{array}{l}\text { 1. Kerapian display oleh toko } \\
\text { 2. Pengkategorian jenis barang yang } \\
\text { teratur } \\
\text { 3. Alunan musik yang dirasakan } \\
\text { konsumen } \\
\text { 4. Aroma dalam toko } \\
\text { 5. Pencahayaan dalam toko yang } \\
\text { baik } \\
\text { 6. Suhu udara dalam toko yang } \\
\text { sesuai }\end{array}$ \\
\hline $\begin{array}{l}\text { Lokasi } \\
\text { (X2) }\end{array}$ & $\begin{array}{l}\text { Lokasi adalah } \\
\text { letak atau } \\
\text { toko pengecer } \\
\text { pada daerah } \\
\text { yang strategis } \\
\text { sehingga dapat } \\
\text { memaksimum } \\
\text { kan laba. Basu } \\
\text { Swasta dan } \\
\text { Irawan } \\
(2003: 339)\end{array}$ & $\begin{array}{ll}\text { a. } & \text { Keterjangkauan lokasi. } \\
\text { b. Kelancaran akses menuju lokasi. } \\
\text { c. Kedekatan lokasi }\end{array}$ \\
\hline
\end{tabular}

Teknik Analisis Data Uji Vadilitas 
Uji vadilitas adalah suatu langkah pengujian yang dilakukan terhadap isi (konten) dari suatu instrumen yang digunakan dalam suatu penelitian (Sugiyono, 2015). Validitas suatu butir pertanyaan dapat dilihat dari output StatisticalProgram For Social Science (SPSS) pada pada tabel dengan judul Item-Total Statistisc.Suatu butir pertanyaan dikatakan valid jika nilai dari Corrected Item-Total Corrected $>0,30$. Uji validitas sebaiknya dilakukan secara terpisah pada lembar kerja yang berbeda antara satu konstruk variabel dengan konstruk variabel yang lain sehingga dapat diketahui butir-butir pertanyaan variabel mana yang paling banyak tidak valid. Sehingga pengambilan keputusan adalah:

a. Jika Corrected Item-Total Correlation $>0,30$,maka dimensi tersebut valid

b. Jika Corrected Item-Total Correlation < 0,30, maka dimensi tersebut tidak valid

\section{Uji Reliabilitas}

Uji reliabilitas adalah uji terhadap instrumen yang bila digunakan beberapa kali untuk mengukur objek yang sama akan menghasilkan data yang sama (Sugiyono, 2015). Uji reabilitas dapat dilakukan secara bersama - sama terhadap seluruh butir pernyataan untuk lebih dari satu variabel, namun sebaiknya uji reliabilitas sebaliknya dilakukan pada masingmasing variabel pada lembar kerja yang berbeda sehingga dapat diketahui konstruk variabel mana yang tidak reliabel. Reliabilitas suatu konstuk variabel dikatakan baik jika memiliki nilai Cronbach's Alpha $>0,60$. Sehingga pengambilan keputusan adalah :

a. Jika Cronbach's Alpha> 0,60 maka dimensi pernyataan tersebut reliabel.

b. Jika Cronbach's Alpha $\leq 0,60$ maka dimensi pernyataan tersebut tidak reliabel.

\section{Uji TCR (Tingkat Capaian Responden)}

Menghitung nilai Tingkat Capaian Responden (TCR) masing-masing kategori dari data deskriptif variabel. Rumus uji TCR (Kamener, 2017):

$$
T C R=\frac{\text { Rata }- \text { rataskor }}{5} \times 100 \%
$$

Keterangan :

$\mathrm{TCR}=$ Tingkat Capaian Responden

Menurut Kamener (2017), mengemukakan Kriteria jawaban responden untuk Tingkat Capaian Responden (TCR) adalah sebagai berikut:

Tabel 3

Rentang Skala TCR

\begin{tabular}{ccc}
\hline NO & Angka & Keterangan \\
\hline 1 & $0 \%-54.9 \%$ & Tidak Baik \\
\hline 2 & $55 \%-64.9 \%$ & Kurang Baik \\
\hline 3 & $65 \%-79.9 \%$ & Cukup Baik \\
\hline 4 & $80 \%-89.9 \%$ & Baik \\
\hline 5 & $90 \%-100 \%$ & Sangat Baik \\
\hline
\end{tabular}

Sumber: (Kamener, 2017)

Uji asumsi klasik

Uji Normalitas 
Uji normalitas adalah pengujian untuk mengkaji kenormalan variabel yang diteleti apakah data tersebut berdistribusi normal atau tidak (Sugiyono, 2015). Indikator yang digunakan Uji kolmogrov-smirnov dengan pedoman yaitu :

a. Jika nilai signifikansi $>0,05$, maka berdistribusi normal

b. Jika nilai signifikans $<0,05$, maka tidak berdistribusi normal

\section{Uji Multikolinearitas}

Uji multikolinearitas bertujuan untuk menguji apakah model regresi ditemukan adanya korelasi antar variabel bebas (independen), model regresi yang baik seharusnya tidak terjadi korelasi diantara variabel independen (Ghozali, 2011). Indikator uji multikonearitas yaitu apabila nilai tolerance $>0,1$, dan Variance Inflation Factor (VIF) $<10$ maka tidak terjadi gejala multikonearitas sehingga tidak adanya pengaruh antara variabel yang satu dengan variabel yang lainnya.

\section{Uji Heteroskedastisitas}

Uji heteroskedatisitas bertujuan menguji apakah dalam model regresi terjadi ketidaksamaan varians dari residual satu pengamatan ke pengamatan yang lain. (Ghozali, 2011)

\section{Analisis Regresi Berganda}

Analisa regresi linear berganda adalah prosedur statistik untuk menganalisa hubungan antara variabel dependen dan variabel independen. Jika terdapat dua atau lebih variabel bebas maka menggunakan analisa regresi linear berganda (Prabowo \& Fathoni, 2016). Dengan demikian dapat diketahui seberapa besar pengaruh antara variabel bebas terhadap variabel terikat. Dalam penelitian ini digunakan persamaan regresi berganda sebagai berikut :

$$
\begin{array}{ll}
\mathrm{Y} & =\alpha+\beta 1 \mathrm{X} 1+\beta 2 \mathrm{X} 2+\mathrm{e} \\
\mathrm{Y} & =\text { Minat Beli Konsumen } \\
\mathrm{X} 1 & =\text { Suasana Toko } \\
\mathrm{X} 2 & =\text { Lokasi } \\
\alpha & =\text { Koefisien Konstanta } \\
\beta 1 & =\text { Koefisien regresi untuk Suasana Toko } \\
\beta 2 & =\text { Koefisien untuk Lokasi } \\
\mathrm{e} & =\text { Standar } \text { error }
\end{array}
$$

\section{Uji Hipotesis}

Uji T

Menurut Sugiyono (2015), uji statistik t pada dasarnya menunjukkan seberapa jauh pengaruh satu variabel independen secara individual dalam menerangkan variabel dependen. Pengujian dilakukan dengan menggunakan signifikan level 0,05 $(\alpha=5 \%)$. Penerimaan atau penolakan hipotesis dilakukan dengan kriteria:

a. Jika nilai signifikan >0,05 maka hipotesis ditolak (koefisien regresi tidak signifikan). Ini berarti secara parsial variabel independen tidak mempunyai pengaruh secara signifikan terhadap variabel dependen.

b. Jika nilai signifikan $\leq 0,05$ maka hipotesis diterima (koefisien regresi signifikan). Ini berarti secara parsial variabel independen tersebut mempunyai pengaruh yang signifikan terhadap variabel dependen.

\section{Uji $\mathbf{R}^{2}$}


Koefisien determinasi pada intinya mengukur seberapa jauh kemampuan model dalam menerangkan variasi variabel dependen. Nilai koefisien determinasi adalah antara nol dan satu. Nilai Adjusted $R^{2}$ yang kecil berarti kemampuan variabel-variabel independen dalam menjelaskan variasi variabel dependen sangat terbatas, dimana hal yang ditunjukkan oleh besarnya koefisien determinasi antara nol (0) dan (1). Koefisien determinasi nol variabel independen sama sekali tidak berpengaruh terhadap variabel dependen. (Sugiyono, 2015).

\section{HASIL DAN PEMBAHASAN}

Teknik Analisis Data

Uji validitas

Uji Validitas Variabel Suasana Toko (X1)

Tabel 4

Hasil Uji Validitas Suasana toko

\begin{tabular}{cccc}
\hline Variabel & $\begin{array}{c}\text { No } \\
\text { Butir }\end{array}$ & $\begin{array}{c}\text { Corrected } \\
\text { Item - Total } \\
\text { Correlation }\end{array}$ & Keterangan \\
& 1 & 0,575 & Valid \\
\cline { 2 - 4 } & 2 & 0,509 & Valid \\
\cline { 2 - 4 } SUASANA & 3 & 0,601 & Valid \\
\cline { 2 - 4 } TOKO & 4 & 0,626 & Valid \\
\cline { 2 - 4 } & 5 & 0,563 & Valid \\
\cline { 2 - 4 } & 6 & 0,612 & Valid \\
\cline { 2 - 4 } & 7 & 0,480 & Valid \\
\cline { 2 - 4 } & 8 & 0,400 & Valid \\
\hline
\end{tabular}

Berdasarkan tabel diatas bahwa dari 9 butir pernyataan variabel suasana toko dapat digunakan untuk penelitian lebih lanjut karena nilai Correcteed Item - Total Correlationlebih besar dari 0,300 .

Uji Validitas Variabel Lokasi (X2)

Tabel 5

Hasil Uji Validitas Lokasi

\begin{tabular}{|c|c|c|c|}
\hline Variabel & No Butir & $\begin{array}{l}\text { Correcteed Item - } \\
\text { Total Correlation }\end{array}$ & Keterangan \\
\hline \multirow{10}{*}{ Lokasi } & 1 & 0,585 & Valid \\
\hline & 2 & 0,403 & Valid \\
\hline & 3 & 0,474 & Valid \\
\hline & 4 & 0,440 & Valid \\
\hline & 5 & 0,484 & Valid \\
\hline & 6 & 0,707 & Valid \\
\hline & 7 & 0,554 & Valid \\
\hline & 8 & 0,546 & Valid \\
\hline & 9 & 0,505 & Valid \\
\hline & 10 & 0,523 & Valid \\
\hline
\end{tabular}


Berdasarkan tabel diatas bahwa dari 10 butir pernyataan variabel lokasi dapat digunakan untuk penelitian lebih lanjut karena nilai Correcteed Item - Total Correlationlebih besar dari 0,300.

Uji Validitas Minat Beli (Y)

Tabel 6

Hasil Uji Validitas Variabel Minat Beli

\begin{tabular}{cccc}
\hline Variabel & $\begin{array}{c}\text { No } \\
\text { Butir }\end{array}$ & $\begin{array}{c}\text { Corrected } \\
\text { Item - } \\
\text { Total } \\
\text { Correlation }\end{array}$ & Keterangan \\
& 1 & 0,513 & Valid \\
\cline { 2 - 4 } & 2 & 0,510 & Valid \\
\cline { 2 - 4 } MINAT & 3 & 0,519 & Valid \\
\cline { 2 - 4 } BELI & 4 & 0,626 & Valid \\
\cline { 2 - 4 } & 5 & 0,507 & Valid \\
\cline { 2 - 4 } & 6 & 0,649 & Valid \\
\cline { 2 - 4 } & 7 & 0,660 & Valid \\
\cline { 2 - 4 } & 8 & 0,455 & Valid \\
\hline
\end{tabular}

Berdasarkan tabel diatas bahwa dari 9 butir pernyataan variabel minat beli dapat digunakan untuk penelitian lebih lanjut karena nilai Correcteed Item - Total Correlationlebih besar dari 0,300.

Uji Reliabilitas

Tabel 7

Hasil Uji Reliabilitas

\begin{tabular}{|c|c|c|c|c|}
\hline \multirow[b]{2}{*}{ Variabel } & \multicolumn{2}{|c|}{$\mathrm{N}=49$} & \multirow[b]{2}{*}{$\begin{array}{c}\text { Role } \\
\text { of thumb }\end{array}$} & \multirow[b]{2}{*}{ Keputusan } \\
\hline & $\begin{array}{c}\text { Jumlah } \\
\text { Butir } \\
\text { Pernyataan }\end{array}$ & $\begin{array}{l}\text { Cronbach's } \\
\text { alpha }\end{array}$ & & \\
\hline Suasana Toko & 9 & 0,750 & 0,6 & Reliable \\
\hline Lokasi & 10 & 0,744 & 0,6 & Reliable \\
\hline Minat Beli & 9 & 0,748 & 0,6 & Reliable \\
\hline
\end{tabular}

Dari tabel di atas terlihat seluruh instrument berdasarkan analisis reliabilitas atas variabel penelitian menunjukkan bahwa nilai Cronbanch's alpha untuk semua variabel adalah diatas 0,6 . Untuk itu seluruh variabel bisa dikatakan reliable (dapat diterima). 


\section{Uji TCR}

Dari hasil Uji TCR X1 susana toko maka dapat dilihat bahwa item pernyataan nomor lima merupakan persentase paling rendah sebesar 70,20\% dan item pernyataa nomor satu merupakan persentase paling tinggi sebesar $82,40 \%$. Kesimpulan rata-rata dari tanggapan responden terhadap variabel Suasana Toko berada pada tingkatan Baik, yaitu sebesar $76.24 \%$

Dari hasil Uji TCR X2 lokasi maka dapat dilihat bahwa item pernyataan nomor tujuh merupakan persentase paling rendah sebesar $75,0 \%$ dan item pernyataan nomor satu merupakan persentase paling tinggi sebesar 86,80\%. Kesimpulan rata-rata dari tanggapan responden terhadap variabel Lokasi berada pada tingkatan Baik, yaitu sebesar $80.70 \%$

Dari hasil Uji TCR Y minat beli konsumen maka dapat dilihat bahwa item pernyataan nomor enam merupakan persentase paling rendah sebesar $66,80 \%$ dan item pernyataan nomor lima merupakan persentase paling tinggi sebesar $79,80 \%$. Kesimpulan rata-rata dari tanggapan responden terhadap variabel Minat Beli berada pada tingkatan cukup baik, yaitu sebesar $64,42 \%$.

\section{Uji Asumsi Klasik}

\section{Uji Normalitas}

Tabel 8

Hasil Uji Normalitas

\begin{tabular}{lr}
\hline & \multicolumn{2}{c}{$\begin{array}{c}\text { Standardized } \\
\text { Residual }\end{array}$} \\
\hline Kolmogorov-Smirnov Z & 0,096 \\
Asymp. Sig. (2-tailed) & 0,096 \\
\hline
\end{tabular}

Berdasarkan hasil uji normalitas diatas diketahui bahwa nilai Asymp. Sig. (2-tailed) untuk variabel Suasana Toko, variabel Lokasi, variabel Minat Beli sebesar 0,096 artinya semua nilai pada variabel yang diuji menunjukkan Nilai signifikan (Sig) diatas nilai $(\alpha=$ 0,05). Melalui hasil pengujian normalitas di atas, disimpulkan bahwa seluruh data variabel dalam penelitian ini (Suasana Toko, Lokasi, dan Minat Beli) telah terdistribusi secara normal.

\section{Uji Multikolinearitas}

Tabel 9

\section{Hasil Uji Multikolinearitas}

\begin{tabular}{|c|c|c|c|}
\hline \multirow{2}{*}{\multicolumn{2}{|c|}{ Model }} & \multicolumn{2}{|c|}{ Collinearity Statistics } \\
\hline & & Tolerance & VIF \\
\hline \multirow[t]{3}{*}{1} & (Constant) & & \\
\hline & Suasana Toko & 0,590 & 1,695 \\
\hline & $\overline{\text { Lokasi }}$ & 0,590 & 1,695 \\
\hline
\end{tabular}

Sumber : Data SPSS 16 (Data diolah tahun 2018) 
Berdasarkan hasil uji multikolinearitas diatas menunjukkan nilai tolerance dari setiap variabel bebas $0,590>0,1$ dan nilai VIF 1,695 < 10, maka kesimpulannya tidak terjadi masalah multikonearitas.

\section{Uji Heteroskedastisitas}

Tabel 10

Hasil Uji Heteroskedastisitas

\begin{tabular}{ccccc}
\hline No & Variabel & Sig & Alpha & Keterangan \\
\hline 1 & Suasana Toko & 0.413 & 0,05 & Tidak Heteroskedastisitas \\
\hline 2 & Lokasi & 0.736 & 0,05 & Tidak Heteroskedastisitas \\
\hline
\end{tabular}

Berdasarkan hasil uji heteroskedastisitas diatas, dapat diperoleh nilai signifikansi dari variabel Suasana Toko (X1) dan Lokasi (X2) tidak terjadi heteroskedastisitas, karena nilai signifikan dari semua variabel lebih besar dari tingkat signifikan yang digunakan $(\alpha=0,05)$. Dengan demikian dapat disimpulkan bahwa data hasil penelitian tidak mengalami kasus heteroskedastiditas.

\section{Analisis Regresi Linear Berganda \\ Hasil Uji Regresi Linear Berganda}

\section{Tabel 11}

\section{Hasil Uji Regresi Linear Berganda}

\begin{tabular}{|c|c|c|c|c|c|c|}
\hline \multicolumn{7}{|c|}{ Coefficientsa } \\
\hline \multirow{2}{*}{\multicolumn{2}{|c|}{ Model }} & \multicolumn{2}{|c|}{$\begin{array}{c}\text { Unstandardized } \\
\text { Coefficients }\end{array}$} & $\begin{array}{l}\text { Standardized } \\
\text { Coefficients }\end{array}$ & \multirow[b]{2}{*}{$\mathrm{t}$} & \multirow[b]{2}{*}{ Sig. } \\
\hline & & B & $\begin{array}{l}\text { Std. } \\
\text { Error }\end{array}$ & Beta & & \\
\hline \multirow[t]{3}{*}{1} & (Constant) & 13.004 & 4.205 & & 3.092 & .003 \\
\hline & $\begin{array}{l}\text { St : suasana } \\
\text { toko }\end{array}$ & .588 & .130 & .515 & 4.527 & .000 \\
\hline & L : lokasi & -.010 & .130 & -.009 & -.079 & .937 \\
\hline
\end{tabular}

Sumber : Data SPSS 16 (Data diolah tahun 2018)

Berdasarkan hasil regresi yang didapat maka dibuat persamaan linear berganda sebagai berikut :

$\mathrm{Y}=13,004+0,588(\mathrm{X} 1)-0.010(\mathrm{X} 2)+\mathrm{e}$

Persamaan regresi linear berganda diatas mempunyai arti sebagai berikut :

1. Konstanta mempunyai nilai positif sebesar 13,004 . Hal ini berarti apabila Suasana Toko dan Lokasi bernilai nol, maka masih bernilai tetap 13,004.

2. Nilai koefisien regresi Suasana Toko adalah 0,588 artinya apabila Suasana Toko meningkat sebesar satu satuan, maka meningkat 0,588 .

3. Nilai koefisien regresi Lokasi adalah $-0,010$ artinya apabila Lokasi meningkat satu satuan maka berkurang $-0,010$. 
Uji Hipotesis

Uji T

Tabel 12

Hasil Uji T

\begin{tabular}{llrr}
\hline \multicolumn{1}{c}{ Model } & \multicolumn{2}{c}{ S } & \\
\hline 1 (Constant) & 3,092 & 0,003 \\
Suasana Toko & 4,527 & 0,000 \\
Lokasi & $-0,079$ & 0,937 \\
\hline
\end{tabular}

Sumber : Data SPSS 16 (Data diolah tahun 2018)

Berdasarkan hasil uji t pada tabel 4.15 dapat dilkakukan analisa sebagai berikut :

1. Hasil uji t Suasana Toko terhadap Minat Belidiperoleh t hitung $(4,527)>\mathrm{t}$ tabel $(1,6772)$ dan nilai signifikansi sebesar 0,000 . Hal ini menunjukkan adanya pengaruh positif dan signifikan $(0,000<0,05)$. Sehingga menerima hipotesis $\mathrm{H} 1$ yang menyatakan Suasana Toko berpengaruh positif dan signifikan terhadap Minat Beli

2. Hasil uji t Lokasi terhadap Minat Belidiperoleh thitung $(-0,079)<\mathrm{t}$ tabel $(1,6772)$ dan nilai signifikansi sebesar 0,937 . Hal ini menunjukkan adanya pengaruh yang negatif dan tidak signifikan $(0,937>0,05)$. Sehingga menolak hipotesis yang menyatakan Lokasi berpengaruh negatif dan signifikan terhadap Minat Beli.

Uji $\mathbf{R}^{2}$

\section{Tabel 13 \\ Hasil Uji $\mathbf{R}^{2}$}

Model Summary

\begin{tabular}{lrrrr}
\hline Model & R & R Square & Adjusted R Square & $\begin{array}{c}\text { Std. Error of the } \\
\text { Estimate }\end{array}$ \\
\hline 1 & $.509^{\mathrm{a}}$ & 0,259 & 0,244 & 4,55744 \\
\hline
\end{tabular}

Sumber : Data SPSS 16 (Data diolah tahun 2018)

Besarnya koefisien determinasi dapat dilihat padaAdjusted $R$ Square adalah sebesar 0,244, yang mempunyai arti bahwa Minat Beli dijelaskan oleh variabel Suasana Toko dan Lokasi sebesar $24,4 \%$, sedangkan sebesar 74,3\% dijelaskan oleh variabel lain yang tidak diteliti dalam penelitian ini contohnya variabel Promosi.

\section{Pembahasan}

\section{Pengaruh Suasana Toko terhadap Minat Beli}

Berdasarkan hasil pengujian hipotesis pertama, ditemukan bahwa variabel Suasana Toko berpengaruh positif dan signifikan terhadap MInat Beli pada Xmart Ulak Karang. Berdasarkan hasil uji t pada variabel Suasana Toko sebesar 4,527 dan signifikansinya sebesar 0,000 yang lebih kecil dari 0,05. Hal ini dapat diartikan bahwa variabel Suasana Toko berpengaruh positif dan signifikan terhadap Minat Beli, dengan demikian, hipotesis pertama (H1) dalam penelitian ini yang menyatakan bahwa Suasana Toko berpengaruh positif dan signifikan terhadap Minat Beli pada Xmart Ulak Karang, dinyatakan dapat diterima. Hal ini berarti bahwa apabila Suasana Toko bertambah akan menyebabkan meningkatnya Minat Beli pada Xmart Ulak Karang, 


\section{Pengaruh Lokasi terhadap Minat Beli}

Berdasarkan hasil pengujian hipotesis kedua, ditemukan bahwa variabel Lokasi berpengaruh negatif dan tidak signifikan terhadap Minat Beli pada Xmart Ulak Karang, Berdasarkan hasil uji t variabel Lokasi sebesar -0,079 dan signifikansinya sebesar 0,937 yang lebih besar dari 0,05. Hal ini dapat diartikan bahwa variabel Lokasi berpengaruh negatif dan tidak signifikan terhadap Minat Beli, dengan demikian, hipotesis kedua (H2) dalam penelitian ini yang menyatakan bahwa Lokasi berpengaruh negatif dan tidak signifikan terhadap Minat Beli pada Xmart Ulak Karang, dinyatakan ditolak.

Hal ini bermakna tingkat Minat Beli akan tetap terjadi pada Xmart Ulak Karang, meskipun ada atau tidaknya tingkat Lokasi di perusahaan tersebut.

\section{Kesimpulan}

Berdasarkan hasil pengujian dan analisis data mengenaidengan menggunakan analisis regresi linear berganda, dapat disimpulkan bahwa :

1. Suasana Toko, nilai koefisien regresi untuk variabel suasana toko sebesar 0,588 bertanda positif dengan nilai Sig. $0,000<0,05$ yang berarti bahwa suasana toko mempunyai pengaruh positif dan signifikan terhadap minat beli. Dengan demikian dapat disimpulkan hipotesis pertama diterima.

2. Lokasi, nilai koefisien regresi untuk variabel lokasi sebesar $-0,010$ bertanda negatif dengan nilai Sig. 0,937> 0,05 yang berarti bahwa lokasi mempunyai pengaruh negatif dan tidak signifikan terhadap minat beli. Dengan demikian dapat disimpulkan hipotesis kedua di tolak.

\section{UCAPAN TERIMA KASIH}

Dengan selesainya penulisan artikel ini, penulis mengucapkan terima kasih kepada pihak-pihak yang membantu selama proses penulisan.

1. Bapak febryandhie Ananda, SE, M.Si, selaku Ketua di STIE "KBP” Padang.

2. Ibu Lidya Martha, SE, MM selaku Wakil Ketua di STIE “KBP” Padang.

3. Ibu Febsri Susanti, SEI, MM selaku Ketua Program Studi Manajemen di STIE "KBP" Padang.

4. Ibu Lidya Martha, SE, MM selaku Penasehat Akademik Program Studi Manajemen di STIE "KBP” Padang.

5. Jhon Fernos, SE, MM selaku Pembimbing Proposal Skripsi di STIE “KBP” Padang.

\section{DAFTAR PUSTAKA}

Adiba. (2016). Pengaruh Suasana Toko dan Lokasi Terhadap Minat Beli Konsumen Pada Toko Aurora Shop Samarinda. eJournal Administrasi Bisnis, 4(34), 670-682.

Ghozali, I. (2011). Aplikasi Analisis Multivariate Dengan Program IBM SPSS 20. In book (pp. 1-298). Semarang: Badan Penerbit Universitas Diponegoro.

Ibrahim, C. M. dan M. (2017). Pengaruh Pemilihan Lokasi terhadap Minat Konsumen, 4(1).

Julianti, N. L., Nuridja, M., \& Meitriana, M. A. (2014). Pengaruh Suasana Toko (Store Atmosphere) Terhadap Minat Beli Konsumen Pada Toserbanusa Dua Permai. Jurnal Pendidikan Ekonomi Undiksha, 4(1). Retrieved from https://ejournal.undiksha.ac.id/index.php/JJPE/article/view/4119 
Kamener, D. (2017). Faktor - Faktor Yang Mempengaruhi Kualitas Strategi Bersaing Industri Ukm Bordiran / Sulaman Di Kota Padang. Journal of Economic and Economic Education, 5(1), 90-105. https://doi.org/doi.org/10.22202/economica.2015.5.1.688

Marlius, D. (2016). Pengaruh Bauran Pemasaran Jasa Terhadap Minat Nasabah Dalam Menabung Pada Bank Nagari Cabang Muaralabuh. https://doi.org/10.31227/osf.io/vdqgx

Marlius, D. (2017). Keputusan Pembelian Berdasarkan Faktor Psikologis Dan Bauran Pemasaran Pada PT. Intercom Mobilindo Padang. Jurnal Pundi. Volume 1. No. 1. Hal. 57-66. https://doi.org/10.31575/jp.v1i1.9

Prabowo, N. S., \& Fathoni, A. (2016). Pengaruh Kepuasan Kerja Dan Stres Kerja Terhadap Engangement Employee Dengan Turnover Intention Sebagai Variabel Intervening Pada PT. Ara Shoes Semarang. Jurnal Manajemen, 1-7.

Priyanti,Y. Susanti, F. Aziz, N. (2017). Minat Beli Konsumen Toko Sepatu Bata Dipasar Raya Padang Dilihat Dari Sikap Dan Iklan. Jurnal Pundi, Vol. 01, No. 02

Sugiyono. (2015). Statistik Nonparametris Untuk Penelitian. Book. Bandung: CV. Alvabeta.

Wibowo, B. (2015). Pengaruh Suasana Toko, Promosi Dan Lokasi Terhadapminat Beli Di Planet Distro Kota Banjarnegara Skripsi. niversitas Negeri Yogyakarta.

Widiastuti, N. (2017). Pengaruh Promosi, Lokasi dan harga terhadap Minat Beki Konsumen. 